\title{
Prevalence of Some Trace and Toxic Heavy Metals in Raw Cow's and buffaloe's Milk
}

\section{Birendra K. Roy}

Dept. of Pharmacology and Toxicology, Faculty of Veterinary Science \& A. H., B. A. U., Ranchi-834006, India

In the present investigation, the levels of certain metals, present in 200 milk samples, 100 each of cows and buffaloes of different locations of Ranchi were analyzed by Atomic Absorption Spectrophometer for presence of Iron(Fe),cadmium $(\mathrm{Cd})$,Manganese $(\mathrm{Mn})$,lead $(\mathrm{Pb})$, zinc $(\mathrm{Zn})$ and nickel $(\mathrm{Ni}) . \mathrm{Pb}$ in milk of cows ranged between $0.2864+0.0365$ to $0.3913+$ $0.0497 \mathrm{mg} / \mathrm{L}$ and the same ranged from $0.0771+0.0211 \mathrm{mg} / \mathrm{L}$ to $0.2260+0.0419 \mathrm{mg} / \mathrm{L}$ in buffaloes milk. The average Cd concentrations ranged from $0.0600+0.0145$ to $0.1340+0.0188 \mathrm{mg} / \mathrm{L}$ in cows milk and $0.0246+0.0141 \mathrm{mg} / \mathrm{L}$ to $0.0494+0.0138 \mathrm{mg} / \mathrm{L}$ in buffaloes. The mean concentrations of $\mathrm{Cu}$ in cow milk were found in the range of $0.1465+$ 0.0108 to $0.1520+0.0033 \mathrm{mg} / \mathrm{L}$ and in buffaloes from $0.1560+0.0064 \mathrm{mg} / \mathrm{L}$ to $0.1791+0.0049 \mathrm{mg} / \mathrm{L}$. The mean concentrations of $\mathrm{Zn}$ were found between $0.3327+0.0373 \mathrm{mg} / \mathrm{L}$ in cows milk and $0.4770+0.461$ to $0.7157+0.0289$ $\mathrm{mg} / \mathrm{L}$ in buffaloes. Out of 100 milk samples of cows, 80 samples were observed to be above MRL and 60 and 52 were above MRL for $\mathrm{Cd}$ and $\mathrm{Pb}$.Out of 100 milk samples of buffaloes 96,15 and 14 were above MRL for $\mathrm{Zn}, \mathrm{Cd}$ and $\mathrm{Pb}$ respectively. 